\title{
Assessment of pollution trend of heavy metals in soils in the vicinity of Nigerian Gas Company in Ughelli, Delta State
}

\author{
Godwin E. NWAJEI \\ Department of Chemistry, Delta State University, P.M.B. 1 Abraka, Nigeria.
}

\begin{abstract}
Topsoil and subsoil obtained in the vicinity of the Nigerian Gas Company were digested and analysed for some selected trace metals using atomic absorption spectrophotometer of model pye unicam SP 2900. The trace metals determined include nickel, copper, iron, barium, lead, cadmium and zinc respectively. The analytical results obtained revealed that the aforementioned trace metals were detected and metal concentrations were highly varied for both topsoil and subsoil. Soil samples (topsoil and subsoil) showed significant higher metal concentrations when compared with those of the background samples. The mean concentrations of nickel, iron, barium, lead and cadmium in topsoil $(0-15 \mathrm{~cm})$ were lower than those values obtained in subsoil $(15-30 \mathrm{~cm})$. The results of this study were also compared with other similar studies within Nigeria. The results indicate significant enrichment of trace metals in the studied areas. The metal enrichment reported in this study is traceable to petroleum activities in the Niger Delta region.
\end{abstract}

(c) 2011 International Formulae Group. All rights reserved.

Keywords: Petroleum activities; topsoil and subsoil; trace metals; Nigeria Gas Company; enrichment factors.

\section{INTRODUCTION}

Heavy metals are natural components of the Earth's crust. They cannot be degradable or destroyed. Heavy metals can enter into the soil horizons through industrial discharges and anthropogenic wastes or even from acid rain. The main threats to human health from heavy metals are associated with soils exposed to lead, cadmium, mercury and arsenic. These metals have been extensively studied and their effects on human health regularly reviewed by international bodies such as the World Health Organisation (WHO) (Jarup, 2003). People may be exposed to potentially harmful chemical, physical and biological agents in air, food, water or soil (Bergiund et al., 2001). Emissions of heavy metals to the environment occur via a wide range of processes and pathways, including to the air, (e.g, during combustion, extraction and processing), to surface waters (via runoff and release from storage and transport) and to the soil and hence into groundwaters and crops (Jarup, 2003). Non-urban soils have been reported to be polluted, but urban soils have higher concentration of trace metal pollutants (Chirenje et al., 2003). Worldwide increasing level of industrialization and urbanization has led to environmental pollution (Filazi et al., 2003). There has been a report of contamination of the Nigerian environment by petroleum products (Kakulu and Osibanjo, 1992). The variations in the trace metal content of the soil around the major industrial areas of Northern Eastern Nigeria gave an indication of an unequal 
distribution of the metals (Inuwa et al., 2007), Soil, whether in urban or agricultural areas, represents a major sink for metals released into the environment from a variety of athropogenic sources (lwegbue et al., 2009).

Industrial wastes and anthropogenic wastes were the major contributors of the elevated metal concentrations in soils from Onitsha metropolis (Nwajei et al., 2007). Many industrial processes such as smelting burning of fossil fuels, petroleum prospecting and mining, produce heavy metals which if not properly and carefully controlled end up in soils (Osuji and Onojake, 2004). Metals are very common contaminant at 'superfund' sites in US, and similarly contaminated sites worldwide. Long- term deposition of metals in soils can lead to accumulation, transport and biotoxicity/zootoxicity caused by mobility and bioavailability of significant fraction of the metals (Adriano et al., 2002). The fate of trace metals in the soil environment is dependent on both soil properties and environmental factors. The discharge of effluents in Noyyal River basin has caused severe pollution of both the surface and groundwater in Taruppur region and has also contaminated agricultural land (Greetha et al., 2008).

The problem of trace metals concentration in soils can be traced to industrial wastes and emissions from fossil fuels which contain toxic and hazardous substances most of which can be detrimental to human health. Ughelli is one of the homes of Nigerian Gas Company, which is capable of discharging natural gas and effluent into the natural soil. It is suspected that these wastes arising from the gas company might contaminate the topsoil and subsoil; hence, it became necessary for this study. The objectives, therefore is to determine the metal concentration in topsoil and subsoil and to determine the pollution status, if any.

\section{MATERIALS AND METHODS}

Ughelli is one of the urban towns in Delta State of Nigeria. It is located within the sedimentary lowland which lies immediately north of the coastal swamp area of the Niger
Delta between latitude $3^{\circ}$ and $6^{\circ} \mathrm{N}$ and longitude $5^{\circ}$ and $8^{\circ} \mathrm{E}$ in continental margin of the Gulf of Guinea in equatorial of West Africa. Specifically, Ughelli North has over twelve oil producing communities. There are net work of pipelines, flow lines and many oil wells. The Shell Petroleum Development Company/Nigerian National Petroleum Corporation (SPDC/NNPC) gas compressor plant station and the Nigerian Gas Company are located in Ughelli and its environs.

Soil samples were obtained from four sites in the vicinity of the Nigerian Gas Company and control samples was collected about $6 \mathrm{~km}$ away from Ughelli metropolis along the Patani high way. Topsoil $(0-15 \mathrm{~cm})$ and subsoil $(15-30 \mathrm{~cm})$ were collected by manually driven a $1.5 \mathrm{~m}$ stainless steel corer as deep as possible. The samples were collected at distance of about $100 \mathrm{~m}$ apart. The topsoil and subsoil were transferred into clean and labelled plastic containers for further treatment in the laboratory. The soil samples were oven dried at $105{ }^{\circ} \mathrm{C}$ to constant weight for 6 hours (Walinga et al., 1989) the ovendried soil samples were crushed and sieved through a $2 \mathrm{~mm}$ mesh and stored at $4{ }^{\circ} \mathrm{C}$ prior to chemical analysis.

$1.0 \mathrm{~g}$ of soil was weighed into acid washed platinum crucible. $20 \mathrm{ml}$ of concentrated $\mathrm{HNO}_{3}$ was added and $2 \mathrm{ml}$ each of $\mathrm{HCIO}_{4}$ and $\mathrm{HCI}$ in the ratio of 10:1:1 analar grade were added and left for about 10 minutes. The mixture in the crucible was heated in a hot plate to approximately $125^{\circ} \mathrm{C}$ (Steinborn and Breen, 1999) with constant stirring and was further transferred into the fume hood for overnight. On cooling, the solution was filtered through no. 42 Whatman filter paper into $100 \mathrm{ml}$ volumetric flask and was made to mark with deionised water. A blank sample was also prepared and digested using the same procedure. The solutions were stored in the refrigerator prior to metal analysis with atomic absorption spectrometry. Quality control was assured by a recovery study of the total analytical procedure carried out for metals in soil samples by spiking analyzed samples with aliquots of metal 
standards and then reanalyzed the samples. A recover, greater than $90 \%$ was achieved.

\section{RESULTS}

Topsoil and subsoil obtained in the vicinity of the Nigerian Gas Company were analysed for trace metals such as nickel, copper, iron, barium, lead, cadmium and zinc respectively. The results obtained revealed that the aforementioned parameters were all detected as shown in Tables 1 and 2, respectively.

\section{DISCUSSION}

There were variations in trace metal concentrations for both topsoil and subsoil in this study. These variations in metal concentrations are an indication that there were unequal distribution of metals in both topsoil and subsoil. The evidence of metal sinks was observed for nickel, iron, barium, lead and cadmium. This is because the metal concentrations at the topsoil $(0-15 \mathrm{~cm})$ were lower than those obtained in subsoil (15- 30 $\mathrm{cm}$ ) for the above mentioned trace metals. Analysis of variance (ANOVA) carried out also revealed the obvious significant difference $(\mathrm{P}>0.05)$ in measured parameters such as nickel, iron, barium, lead and cadmium when the results were compared from topsoil to subsoil. On the other hand, copper and zinc concentrations varied between topsoil and subsoil. The porosity soil nature could account for the metals contamination sink in soils of the Niger Delta region. This has become necessary, since there is a significant increase in metal values in soil with depth.

A close look at the results showed that samples 01-04 metal values exceeded those of the control or background samples. This is an indication that both topsoil and subsoil have been contaminated by trace metals due to activities of the petroleum industry in Ughelli. The levels of trace metals in the control soil sample are also an indication that other industrial wastes and anthropogenic wastes arising from Ughelli and its' environs have contributed to the presence of these metal analysed in this study.

Lead, iron, barium and cadmium concentrations in topsoil in this study were lower than those obtained by Nwajei and lwegbue, (2007) in surface soils around the Uwelu motor spare parts market, Benin City (0.20- $4.60 \mathrm{mg} / \mathrm{kg}$ for $\mathrm{Cd} ; 60.00-71.00 \mathrm{mg} / \mathrm{kg}$ for $\mathrm{Pb} ; 14080-38600 \mathrm{mg} / \mathrm{kg}$ for $\mathrm{Fe}$ and 1.40 $2.40 \mathrm{mg} / \mathrm{kg}$ for $\mathrm{Ba}$ respectively). Iron, zinc and lead were higher than those values reported by Adeyeye and Ayejuyo (2002) $(10.10 \mathrm{mg} / \mathrm{kg}$ for $\mathrm{Fe} ; 648 \mathrm{mg} / \mathrm{kg}$ for $\mathrm{Zn}$ and $0.14 \mathrm{mg} / \mathrm{kg}$ for $\mathrm{Pb}$ ); Rasheed and Awadallah (1998) $(311.0 \mathrm{mg} / \mathrm{kg}$ for $\mathrm{Fe} ; 1.85 \mathrm{mg} / \mathrm{kg}$ for $\mathrm{Zn}$ and $0.220 \mathrm{mg} / \mathrm{kg}$ for $\mathrm{Pb}$ ) and Abulude (2005) $(0.009-0.616 \mathrm{mg} / \mathrm{kg}$ for $\mathrm{Fe} ; 0.418-$ $0.832 \mathrm{mg} / \mathrm{kg} ; 0.014-0.151 \mathrm{mg} / \mathrm{kg}$ for $\mathrm{Pb}$ respectively). This comparison of metal values in this study with those of different studies in Nigeria has shown an evidence of metal contamination of topsoil and subsoil in Ughelli and its' environs. There is no doubt that these elevated concentrations of trace metals will, on the long-term basis, affect the groundwater and plants. Also, through food chain, these toxic trace elements must affect human and aquatic life. These metals remain in the soil environment for quite a long time because they are not degradable or can be destroyed. They are threats to human health.

The pollution trend in this study is not in agreement with the findings of lwegbue et al. (2006). In this study, there is a significant increase in the concentration of metals with depth in all sites except copper and zinc whereas there was a decrease in the concentration of metals with depth in all sites except for zinc as reported by Iwegbue et al. (2006) in soil profiles of automobile waste dumps in Port Harcourt. Variations in soil properties such as $\mathrm{pH}$, organic matter content, cation exchange capacity and clay fraction could account for the contradiction in metal pollution trend. Decrease in the aforementioned soil properties could lead to decrease in the concentrations of metals with depth. On the other hand, increase in soil properties could lead to increase in the concentration of metals with depth (lwegbue et al., 2006).

The computed enrichment factors presented in Table 3 showed high concentrations of all the metals analysed in 
Table 1: Trace metal contents of topsoil analysed in $\mathrm{mg} / \mathrm{kg}$ dry weight $(\mathrm{n}=6)$.

\begin{tabular}{lllllllll}
\hline $\begin{array}{l}\text { Sample } \\
\text { Code }\end{array}$ & $\begin{array}{l}\text { Mean } \pm \text { SD } \\
\text { and CV }(\%)\end{array}$ & Ni & Cu & Fe & Ba & Pb & Cd & Zn \\
& & & & & & & & \\
\hline 01 & Mean \pm SD & $0.320 \pm$ & $7.852 \pm$ & $212.51 \pm$ & $0.451 \pm$ & $0.345 \pm$ & $0.250 \pm$ & $12.350 \pm$ \\
& & 0.052 & 0.886 & 12.325 & 0.035 & 0.005 & 0.008 & 1.262 \\
& CV $(\%)$ & 16.25 & 11.28 & 5.80 & 7.76 & 1.45 & 1.60 & 10.22 \\
\hline 02 & Mean \pm SD & $0.271 \pm$ & $18.55 \pm$ & $415.10 \pm$ & $0.685 \pm$ & $0.592 \pm$ & $0.330 \pm$ & $20.136 \pm$ \\
& & 0.081 & 2.552 & 24.683 & 0.125 & 0.035 & 0.101 & 3.385 \\
& CV $(\%)$ & 29.89 & 13.76 & 5.95 & 27.83 & 5.91 & 3.03 & 16.81 \\
\hline 03 & Mean \pm SD & $0.150 \pm$ & $7.812 \pm$ & $328.45 \pm$ & $0.460 \pm$ & $0.455 \pm$ & $0.370 \pm$ & $15.780 \pm$ \\
& & 0.024 & 0.967 & 41.635 & 0.128 & 0.009 & 0.020 & 0.956 \\
& CV $(\%)$ & 16.00 & 8.58 & 12.70 & 27.83 & 1.98 & 5.41 & 53.71 \\
\hline 04 & Mean \pm SD & $0.250 \pm$ & $11.257 \pm$ & $318.40 \pm$ & $0.620 \pm$ & $0.460 \pm$ & $0.250 \pm$ & $16.050 \pm$ \\
& & 0.062 & 1.286 & 32.224 & 0.185 & 0.010 & 0.060 & 4.085 \\
& CV $(\%)$ & 24.80 & 11.42 & 10.12 & 29.64 & 2.15 & 24.00 & 25.45 \\
\hline Control & Mean \pm SD & $0.100 \pm$ & $0.950 \pm$ & $112.17 \pm$ & $0.049 \pm$ & $0.150 \pm$ & $0.025 \pm$ & $6.750 \pm$ \\
& & 0.003 & 0.420 & 10.325 & 0.008 & 0.005 & 0.003 & 0.872 \\
& CV (\%) & 3.00 & 44.21 & 9.21 & 16.33 & 3.33 & 12.00 & 12.52 \\
\hline
\end{tabular}

Mean $\pm \mathrm{SD}=$ Mean and Standard Deviation

$\mathrm{CV}(\%)=$ Percentage co-efficient of variation

ANOVA $=$ Analysis of variance

Table 2: Trace metal contents in subsoil analysed in $\mathrm{mg} / \mathrm{kg}$ dry weight $(\mathrm{n}=6)$.

\begin{tabular}{lllllllll}
\hline $\begin{array}{l}\text { Sample } \\
\text { Code }\end{array}$ & $\begin{array}{l}\text { Mean } \pm \text { SD } \\
\text { and CV }(\%)\end{array}$ & $\mathbf{N i}$ & $\mathbf{C u}$ & Fe & Ba & Pb & Cd & Zn \\
& & & & & & & \\
\hline 01 & Mean \pm SD & $0.282 \pm$ & $6.320 \pm$ & $301.16 \pm$ & $0.402 \pm$ & $0.414 \pm$ & $0.254 \pm$ & $8.530 \pm$ \\
& & 0.085 & 0.926 & 40.335 & 0.032 & 0.007 & 0.003 & 0.928 \\
& CV $(\%)$ & 30.14 & 14.65 & 13.39 & 7.96 & 1.69 & 11.81 & 10.88 \\
\hline 02 & Mean \pm SD & $0.365 \pm$ & $15.56 \pm$ & $648.67 \pm$ & $0.950 \pm$ & $0.750 \pm$ & $0.311 \pm$ & $12.750 \pm$ \\
& & 0.065 & 1.285 & 50.725 & 0.039 & 0.102 & 0.020 & 1.365 \\
& CV $(\%)$ & 17.81 & 8.26 & 7.82 & 4.11 & 13.60 & 6.43 & 10.71 \\
\hline 03 & Mean \pm SD & $0.850 \pm$ & $6.650 \pm$ & $335.10 \pm$ & $0.560 \pm$ & $0.675 \pm$ & $0.400 \pm$ & $10.470 \pm$ \\
& & 0.036 & 0.080 & 28.728 & 0.028 & 0.082 & 0.035 & 1.825 \\
& CV $(\%)$ & 4.24 & 12.31 & 8.57 & 5.00 & 12.15 & 8.75 & 17.43 \\
\hline 04 & Mean $\pm S D$ & $0.480 \pm$ & $9.453 \pm$ & $426.95 \pm$ & $0.620 \pm$ & $0.476 \pm$ & $0.453 \pm$ & $10.640 \pm$ \\
& & 0.048 & 1.052 & 26.784 & 0.092 & 0.010 & 0.009 & 2.052 \\
& CV $(\%)$ & 10.00 & 11.13 & 6.27 & 14.64 & 2.10 & 1.97 & 18.59 \\
\hline Control & Mean $\pm S D$ & $0.120 \pm$ & $0.990 \pm$ & $128.45 \pm$ & $0.056 \pm$ & $0.180 \pm$ & $0.028 \pm$ & $8.520 \pm$ \\
& & 0.008 & 0.328 & 16.368 & 0.008 & 0.006 & 0.004 & 0.995 \\
& CV $(\%)$ & 6.67 & 33.13 & 12.74 & 14.29 & 3.33 & 14.29 & 11.68 \\
\hline
\end{tabular}

Mean $\pm \mathrm{SD}=$ Mean and Standard Deviation

$\mathrm{CV}(\%)=$ Percentage co-efficient of variation

ANOVA = Analysis of variance 
Table 3: Enrichment Factor (E.F) of metals in topsoil and subsoil in the vicinity of the Nigerian Gas Company, Ughelli.

\begin{tabular}{lccccccccccccccc}
\hline $\begin{array}{l}\text { Sample } \\
\text { Code }\end{array}$ & \multicolumn{4}{c}{ Topsoil $(\mathbf{0 - 1 5} \mathbf{~ c m})$} & \multicolumn{4}{c}{ Subsoil $(\mathbf{1 5}-\mathbf{3 0} \mathbf{~ c m})$} \\
\cline { 2 - 13 } & $\mathbf{N i}$ & $\mathbf{C u}$ & $\mathbf{F e}$ & $\mathbf{B a}$ & $\mathbf{P b}$ & $\mathbf{C d}$ & $\mathbf{Z n}$ & $\mathbf{N i}$ & $\mathbf{C u}$ & $\mathbf{F e}$ & $\mathbf{B a}$ & $\mathbf{P b}$ & $\mathbf{C d}$ & $\mathbf{Z n}$ \\
\hline 01 & 3.20 & 8.27 & 1.90 & 9.20 & 2.30 & 10.00 & 1.83 & 2.35 & 6.38 & 2.35 & 7.18 & 2.30 & 9.07 & 1.00 \\
02 & 2.71 & 19.53 & 3.70 & 13.98 & 3.95 & 14.35 & 2.98 & 3.04 & 15.72 & 5.05 & 16.96 & 4.17 & 11.11 & 1.50 \\
03 & 1.50 & 8.22 & 2.93 & 9.39 & 3.03 & 14.80 & 2.34 & 7.08 & 6.72 & 2.61 & 10.00 & 3.75 & 14.29 & 1.23 \\
04 & 2.50 & 11.85 & 2.84 & 12.65 & 3.07 & 10.00 & 2.38 & 4.00 & 9.55 & 3.32 & 11.07 & 2.64 & 16.18 & 1.25 \\
& & & & & & & & & & & & & & \\
\hline
\end{tabular}

topsoil and subsoil. The enrichment factor is a convenient method for the determination of geochemical trend. The enrichment factor for the elements in different sample locations showed significant variability. The high metal enrichment reported in this study is traceable to petroleum activities in the Niger Delta region. However, for cadmium and barium, the enrichment factors reported in this study are higher than the values previously reported by Nwajei and lwegbue (2007). The results of some selected metals such as nickel, copper, iron barium, lead, cadmium and zinc respectively, in this study, revealed that topsoil and subsoil obtained in the vicinity of the Nigerian Gas Company contains elevated concentrations of iron, lead, cadmium and barium. The metal concentrations in soils in the vicinity of the Nigeria Gas Company exceeded the background soil samples. This is an indication that the petroleum activities around the study area are the major contributor of metals elevation. These metal concentrations in soils studied could contaminate surface water, groundwater and plants. This study has created the awareness of soil pollution around Oil Company operating areas. This will, no doubt, create the opportunities for soil remediation programme to be established if not already established by various oil companies operating in the Niger Delta.

\section{REFERENCES}

Abulude FO. 2005. Trace Heavy Metals Concentration of Soils and Vegetation in the Vicinity of Livestock in Nigeria, Electron. J. Environ. Agric. Food Chem., 4(2): 863-870.

Adeyeye El, Ayejuyo OO. 2002. Assessment of the physicochemical status of a textiles industry effluent and its environment, Pak. J. Sci. Med. Res., 45(1): 10-16.

Adriano DC, Bolan NS, Koo B, Naidu R, Lelie D, Vangronsveldj J, Wenzel WW. 2002. Natural remediation processes: bioavailability interactions in contaminated soils, symposium no 42, paper no 501, 17th WCSS, 14-21 August 2002, Thailand.

Bergiund M, Elinder CG, Jarup L. 2001. Humans Exposure Assessment. An Introduction, WHO/SDE/OEH/01.3.

Chirenje T, Ma LQ, Szulczewski M, Little R, Porter KM, Zillioux E. 2003. Arsenic distribution in Florida urban soils, comparison between Guinesville and Miami. J. Environ. Quality, 32: 109-119.

Filazi A, Baskaya R, Kum C, Hismiogullari SE. 2003. Metal concentrations in tissues of the Black Sea Fish (Mugil auratus) from Sinop-Iclimari, Turkey. Hum. Exp. Toxicol., 22: 85-87.

Geetha A, Palanisamy PN, Sivakumar P, Ganesh-kumar P, Sujatha M. 2008. Assessment of Underground Water Contamination and Effect of Textile Effluents on Noyyal River Basin in and Around Tiruppur Town, Tamilnadu. E-J. Chem., 5(4): 696-705.

Inuwa M, Abdulrahman FW, Bimin-Yauri UA, Ibrahim SA. 2007. Analytical 
assessment of some trace metals in soils around the major industrial areas of northeastern Nigeria. Trends in Applied Sd. Res., 2(6): 515-521.

lwegbue CMA, lsirimah NO, Igwe C, Williams ES. 2006. Characteristic levels of heavy metals in soil profiles of automobile mechanic waste dumps in Nigeria. Environmentalist, 26: 123-128.

Iwegbue CMA, Nwajei GE, Eguavoen O, Ogala JE. 2009. Chemical fractionation of some heavy metals in soil profiles in vicinity of scrap dumps in Warn, Nigeria. Chem. Speci. Bioavail., 21(2): 99-110.

Jarup L. 2003. Hazards of heavy metal contamination. British Medical Bulletin, 68: $167-182$.

Kakulu SE, Osibanjo O. 1992. Pollution studies of Nigerian Rivers: Trace metals levels of surface waters in the Niger Delta area. Int. J. Environ. Studies, 41: 287-291.

Nwajei GE, lwegbue CMA. 2007. Trace Metal Concentrations in Soil in the Vicinity of Uwelu Motor Spare Parts Market, Benin City, Nigeria. J. Chem. Soc. Nigeria, 32(2): 282-286.
Nwajei GE, lwegbue CMA, Okafor MI. 2007. Heavy Metals in Surface Soils under Waste Dumps from Onitsha Nigeria. $J$. Boil. Sci., 7(2): 405-408.

Osuji LC, Onojake CM. 2004. The Ebocha 8 oil Spillage II Fate of associated heavy metals six mouth after. Afr. J. Environ, Assess. Mon., 9: 78-87.

Rasheed MN, Awadallah RM. 1998. Trace elements in Faba bean plant and Soils as determined by atomic absorption spectrophotometer and iron selective electrode. J. Sci. Food Agric., 77: 18-24.

Steinborn M, Breen J. 1999. Heavy Metals in Soils and Vegetation at Shallee Mine, Silvermines, Co. Tipperary. Biology and Environment Proceedings of the Royal Irish Academy, 99B (1): 37-42.

Walinga L, Van-Vark W, Houba VJG, Van der Lee JJ. 1989. Plant Analysis Procedures, Wageningen Agricultural units (soil and plant part 7). A series syllabi, Netherlands, p. 10-167. 